\title{
"You've Been Framed!": Thematization and Ideological Bias in Arabic and English News Reports
}

\author{
Wesam Ali El-Sayed \\ Department of English, Faculty of Al-Alsun (Languages), Minia University \\ wessam.mohamed@minia.edu.eg.
}

Received: April 22, 2020 Accepted: July 16, 2020 Published: October 26, 2020

\begin{abstract}
Within the framework of Critical Discourse Analysis (CDA), the present article investigates the role of thematization in framing news reports in favor of the respective ideologies of the online versions of the English newspapers, The New York Times and The Telegraph (NYT and TG, hereafter), and those of the Arabic newspapers, Al-Ahram and Al-Jazeera (AH and $\mathrm{AJ}$, hereafter). To this end, 40 news reports, 10 from each newspaper, were chosen for analysis. The 40 reports cover 10 major incidents in the period between February 2012 and July 2015. NYT is an American liberal media institution while TG is a British conservative one, and AH is a state-owned Egyptian newspaper while AJ is a global news organization owned by Al-Jazeera Media Network, the Qatari stateowned media conglomerate. The stark difference between the ideologies in both sets of newspapers, coupled with the different cultural background, is mainly reflected in how news reports arrange bits of discourse in order to steer the reader's perception of the news event in a certain ideological direction. Results reveal that each newspaper adjusts its headlines' schematic categories in the way that best serves its ideological goals, with the exception of AJ which sticks to the objective schematic categories predicted to be present in headlines. Additionally, analysis reveals that Arabic news reports depend on thematic markedness in the expression of bias more than the English ones.
\end{abstract}

Keywords: Critical Discourse Analysis (CDA), News Analysis, 
Ideology, Thematization

\section{Introduction}

The media, with all its forms, has proved to be a requisite tool for shaping realities and social identities of nations. Media institutions often project themselves as neutral and impartial news sources. However, as Herman \& Chomsky (1988) put it, their main function is to "inculcate individuals with the values, beliefs, and codes of behavior that will integrate them into the institutional structures of the larger society," (p. 1) which are often compliant with the ideologies of those media institutions.

This undeniable power of the media is basically an issue of how language is exploited and manipulated to serve these ideological goals. Hence, the process of ideological inculcation is rooted in the view of (media) discourse as a "social practice." Fairclough (1995b, pp. 54-5) states that regarding discourse as a social practice means, first, that people can actually 'do' things with language (e.g. imposing their power and ideology). Most importantly, however, "describing discourse as social practice implies a dialectical [or] a two-way relationship: the discursive event is shaped by situations, institutions and social structures, but it also shapes them" (Fairclough and Wodak, 1997: 55; emphasis added, as cited in Richardson, 2007, p. 28).

The dual nature of language, being common and powerful simultaneously, allows for ideologies to pass peacefully. As stated by Fowler (1991), "anything that is said or written about the world is articulated from a particular ideological position: language is not a clear window but a refracting, structuring medium" (p. 10). This paper is mainly an attempt to defamiliarize and uncover the linguistic manifestations of ideology in Arabic and English news texts, mainly through thematization. Consequently, the study also aims to, "equip readers for demystificatory readings of ideology-laden texts," (Fowler, 1996, p.6). These aims are guided by the following research questions: 1 . How far does ideology interfere in reporting news events? 2. How does thematization facilitate bias manifested? What are the similarities/differences between Arabic and English with regard to the expression of bias? 


\section{Ideological State Apparatuses}

Although objectivity is one of the tenets of journalism, "the sourcing and construct of the news is intimately linked with the actions and opinions of (usually powerful) social groups" (Richardson, 2007, p.1). Accordingly, as previously mentioned, the media is one of the most influential ideological vehicles and viewing it as a free and unbiased provider of information is a fallacious proposition because it is inevitably enmeshed in the tangles of ideology. Media institutions are often termed Ideological State Apparatuses (ISA) since their impartiality is almost a utopian concept.

ISAs were first introduced by Louis Althusser (1971) as a complement to Marx's theory of the State. The ISAs are identified as institutions that "present themselves to the immediate observer in the form of distinct and specialized [ones]” (Althusser, 1971, p. 143) which “'function' massively and predominantly by ideology" (p. 146). ISAs are diverse but can be unified in the sense that "the ideology by which they function is always in fact unified" (p. 146). Thus, they are used by powerful people as tools to maintain power over subordinate or dominated groups through invoking their ideology in the ISAs practices. The focus of this paper is on the Communications ISA, precisely, news reports.

\section{News Reports as an Ideological State Apparatus}

Since their invention, newspapers have long been part and parcel of people's daily lives. They intersect excessively with the private lives of individuals and thus, as an important channel of the media, they have the power to "influence [their] knowledge, beliefs, values, social relations, [and] social identities" (Fairclough, 1995b, p.2). Consequently, newspapers are considered to be "our 'window on the world'; our means of contact with a world which ... [is] largely beyond our direct, personal experience. They provide the information from which we draw our 'cognitive maps' of reality” (McNair, 2003, p.23).

Newspapers are used as an ISA by the state as part of the mass media and "their ideological power stems from their ability to say the same thing to millions of people simultaneously" (Fowler, 1991, p.122). Hence, they 
are extremely influential in bringing about social changes, and that is why journalistic discourse is important to study;

[it] is one active element in bringing about such change through shaping understandings, influencing audiences attitudes and beliefs ... and transforming the consciousness of those who read and consume it.

(Richardson, 2007, p. 29)

This undeniable power of the Newspaper ISA is mainly an issue of how language is exploited and manipulated to serve the ideological goals of media institutions. Hence, viewing media language as discourse is almost a must. Fairclough (1989) views discourse as "language use conceived of as socially determined" (p. 22), and to conduct any analysis of discourse means that the purposes for which the linguistic forms are used cannot be disregarded (Brown $\&$ Yule, 1983). Maintaining power and imposing ideologies are some of the potentially-dangerous functions of language use. The type of DA concerned with dissecting the discursive vehicles of power and ideology is Critical Discourse Analysis (CDA).

\section{Theoretical Framework}

\subsection{Critical discourse analysis (CDA) and news analysis}

CDA is considered one of the most relevant approaches to the study of the media in general and news discourse in particular since it focuses on the exercise of power, ideology and bias in discourse and hence contributes to the elicitation of their discursive manifestations in news texts.

It is of great importance that CDA must not be understood as a separate direction or school in discourse studies (Van Dijk, 2001; Meyer, 2001). Rather, it "aims to offer a different "mode" or "perspective" of theorizing, analysis, and application throughout the whole field" (Van Dijk, 2001, p. 354). According to Van Dijk (2001, p. 352), CDA is defined as,

a type of discourse analytical research that primarily studies the way social power abuse, dominance, and inequality are enacted, reproduced, and resisted by text and talk in social and political context.

CDA's scope on language and discourse "was initiated with the 'critical linguistics' that emerged ... at the end of the 1970s" (Van Dijk, 2001, p. 352). Fowler, et al's (1979) seminal work Language and Control has developed a perspective different from the traditional ones in discourse 
studies. (Van Dijk, 2001; Wodak, 2001; Fowler, 1996). The need for a critical perspective to linguistic analysis emanated from the orthodoxy of linguistics as a "descriptive discipline which has no business passing comments on materials which it analyses; neither prescribing usage nor negatively evaluating the substance of its enquiries" (Fowler, 1991, p. 5). In addition, there is a general tendency to ignore or underestimate the role of power in linguistic analysis. Critical Linguistics is primarily concerned with increasing the consciousness of the complex interrelations between language and power (Fairclough, 1989; Wodak, 2001).

Therefore, adopting critical goals in language study is an attempt to make explicit all implicit power relations and ideologies implanted in discourse and consequently "increase consciousness of how language contributes to the domination of some people by others" (Fairclough, 1989, p. 1). It is, therefore, of great importance in CDA not to analyze data as solely representative of their local situations, but rather analyze them as a part of the global situation in which they are embedded.

Hence, the micro communicative events must be analyzed in relation to the macro social structures of which they are simultaneously a producer and a product. CDA entails "investigating verbal interactions with an eye to their determination by, and effects on, social structures" (Fairclough, 1995a, p. 36) because the way a certain discourse is structured is connected with its place in the socioeconomic system (Fowler, et al., 1979). Central to CDA are the notions of discourse and ideology discussed below.

\subsection{CDA's perception of discourse}

CDA views discourse as a social practice and adopts Gee's (1999) view that discourse exists in a kind of dialogue with society: "language simultaneously reflects reality ("the way things are") and constructs (construes) it to be a certain way" (p.82; emphasis in original). Thus, discourse holds an extremely powerful status in CDA; it is vital and influential in structuring and organizing social structures. Barker \& Galasiński (2001) argue that this 'constructionist' view of discourse through discursive acts is manifested in a number of ways: 
- They play a decisive role in the genesis and construction of social conditions.

- They can restore, justify and perpetuate the social status quo. - They may be instrumental in the transformation of the status quo. (p. 65)

Therefore, as Fairclough (1989) notes, discourse's contribution is summarized in its achievement of "social continuity or social change" ( $p$. 37). Discourse has this ability because it is a site for both the exercise of power of dominant people and the resistance of dominated ones. For example, one form of resisting through discourse might result in what Halliday (1976) calls 'anti-language,' where discourse is used as a form of protest eventually contributing to changing a dominant (mostly oppressive) social reality.

\subsection{Ideology as a socio-cognitive concept}

As a concept, ideology has been handled from different parameters as it is often defined within political and economic frameworks (Payne $\&$ Barbera, 2010, p.340). From the French Revolution to the rise of Marxism (marked by Marx and Engel's book, The German Ideology), ideology has gained a variety of connotations, expressed most comprehensively by Althusser (1969) who defined ideology as "an organic part of every social totality" (p. 232). However, a socio-cognitive parameter is the most relevant framework for the purposes of this study and within which ideology is best defined.

Ideology is defined within a socio-cognitive frame as "belief systems ... [that are] socially shared by the members of a collectivity of social actors" (Van Dijk, 2006, p. 116). They are the world views that legitimize everyday practices of group members and provide "coherence to [their] beliefs" (Van Dijk, 2006, p. 116). In the same vein, Hall (2005) defines ideology as

\footnotetext{
The mental frameworks - the languages, the concepts, categories, imagery of thought, and the systems of representation - which different classes and social groups deploy in order to make sense of, figure out and render intelligible the way society works. (pp. 25-6)
}

On the basis that they organize the attitudes and beliefs of group members, Van Dijk (2006) argues that ideologies are learned, and hence, necessarily organized. For example, a racist ideology will teach their holders views about immigration, and feminists will have the same view about, say, abortion (p. 116). However, this organization does not by any 
means entail consistency. Ideologies are often "heterogeneous or inconsistent" because "they are not logical systems, but sociopsychological ones" (p. 118).

\subsection{Ideology, common sense and bias}

Though ideologies are socially shared, they are not always known to or recognized by all members of a social group. Ideologies might "become shared so widely that they seem to have become part of generally accepted attitudes of an entire community, as obvious beliefs, or opinion, or common sense" (Van Dijk, 2006, p. 117). Van Dijk (2006) further explains this by giving the example of language acquisition. All members of a linguistic community can speak a certain language but not all of them are experts or knowledgeable about it. These 'experts' are usually the powerful people in society who naturalize their practices "to win acceptance for them as non-ideological 'common sense"' (Fairclough, 1992, p. 27).

Naturalization, Fairclough (1989) argues, is the "royal road to common sense ... [and ideologies] come to be ideological common sense to the extent that the discourse types which embody them become naturalized" (p. 92). He further states that ideologies must be naturalized because they are

most effective when [their] workings are at least visible ... the more mechanical the functioning of an ideological assumption in the construction of coherent interpretations, the less likely it is to become a focus of conscious awareness, and hence the more secure its ideological status. (p. 85)

Accordingly, an ideology functions perfectly when it ceases to be one and becomes naturalized, unrecognized by the public: "the apparent emptying of the ideological content of discourse is, paradoxically, a fundamental ideological effect: ideology works through disguising its nature, pretending to be what it isn't' (p. 92).

The notion of ideological bias is already included in the practice of 'naturalizing' ideologies. When those who have power try to normalize (and hence impose) their ideologies, they are axiomatically biased towards them. Because discourse is "the favoured vehicle of ideology" (Fairclough, 1989, p.34), bias in the latter leads necessarily to bias in the former. Van Dijk (2006) explains this in reference to the theory of 
discourse processing in cognitive psychology. He makes use of the notion of 'models' to refer to how people mentally perceive experiences in real life: "[a] model is a mental representation of an experience that is, an event people witness, participate in, or read about" (Van Dijk, 1995b, p.14). Additionally, people not only use these models to express their familiarity with life experiences but also use them to "represent their opinions about them" (Van Dijk, 1997, p. 192). While 'discourse processing' through mental models has been primarily occupied with strategies of comprehension, Van Dijk (1997) stresses the role played by mental models "in the much neglected theory of discourse production, viz., as the mental point of departure of all text and talk, from which relevant information may be selected for the strategic construction of their global and local semantic structures" (p. 189).

Bias results when these models are based on ideologically biased social beliefs and attitudes. Therefore, "ideologically biased event models typically give rise to ideological discourses, in which events and actors are described more or less negatively or positively, depending on the ideological bias of the mental model" (Van Dijk, 2006, p. 121).

Accordingly, there is never an 'absolute' version of what discourses are really about, discourses are only the reflection of people's opinions and subjective interpretations of events.

\section{Method of Analysis}

Thematization will be carried out on the schematic level of news reports, through analyzing the structural categories of headlines; the most prominent position in news hierarchy that captures the news report's macroproposition. Additionally, marked themes are to be analyzed (quantitatively and qualitatively) in order to try to discern how news reporters organize chunks of information in the body of their reports.

\subsection{Headlines}

According to Bell (1991), news reports are considered a type of stories told by journalists. "Journalists are professional story-tellers of our age. The fairy tale starts: 'Once upon a time.' The news story begins: 'Fifteen people were injured today when a bus plunged ...'” (p. 147). As a special type of stories, news reports have their own grammar; their own 
schemata. News schemata are considered "the syntax of news stories, the formal categories into which news can be analyzed and their relations to each other" (Bell, 1991, p. 163).

As shown in fig.1 below, news schemata include many categories, including summary, episode, commentary, and verbal reactions. Headlines are probably the most important part of the structure of news reports. Together with the Lead, they constitute the Summary category. The Headline is graphically marked by being put on top of the news report, by large bold letter type. The size and position of headlines are "important strategic cues for perception and attention processes" (p. 161), and can thus be used by journalists to steer the readers' attention to a certain aspect of the reported incident (which raises questions of bias). According to Van Dijk (1986), it has been empirically proven that readers usually recall only the main topic even if they have read the whole news report. Therefore, the headline is vital to the news schema.

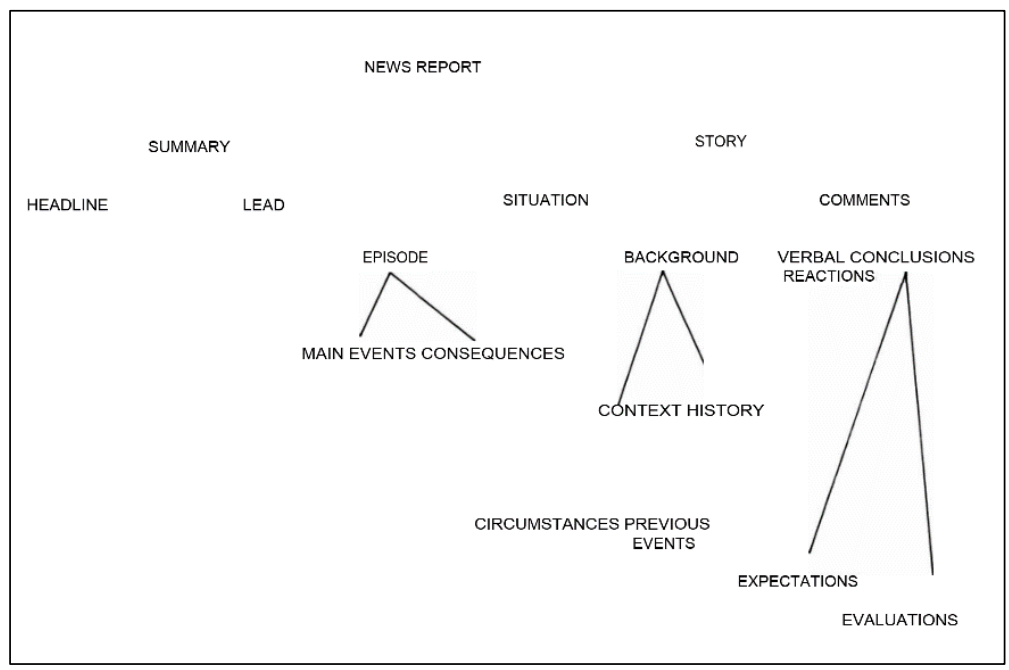

Figure 1: News schema (Van Dijk, 1988, p. 55)

\subsection{Themes}

According to Halliday (2004), the theme of a clause "is the element which serves as the point of departure of the message; it is that which locates and orients the clause within its context" (p. 64). Therefore, Halliday (2004) specifies themes according to their location in the clause; what comes first is considered the theme. Thematic organization is 
"exploited by speakers/writers to provide a structural framework for their discourse, which relates back to their intention and provides a perspective on what follows" (Brown \& Yule, 1983, p. 143). This is particularly important because the structure of news reports is designed so that the most important information is placed in an initial position. Thus, as stated by Bazzi (2009, p. 157):

A conventional news report can put what is seen as the most relevant and important information in the most salient, i.e. thematic positions, whether in the text as a whole or in the clauses and sentences that expand the main themes.

Since "there can be variation in what is chosen as the thematic element in the clause" (Halliday, 2004, p. 66), thematic organization is a powerful tool to elicit bias in the news because it reveals something about the ideology behind the text and enables text producers to steer the discourse in an ideologically favorable direction, which consequently frames the news event and activates particular assumptions for the readers when they interact with the text. This is particularly true because "[s]yntactic prominence expresses or suggests semantic prominence, which, in turn, may be related to prominence of actors and their properties in mental models" (Van Dijk, 1995a, p. 24-5). Thematization occurs when "chunks of the utterance are moved about so as to focus our attention, and to direct our perception, in certain ways" (Fowler, et al., 1979, p. 210). It is important to note that Halliday's (2004) approach to thematic analysis is applicable to the Arabic language, despite the syntactic differences between the two languages. The basic word order of Arabic is VSO while that of English is SVO. However, as noted by Dickens, et. al (2002), "English and Arabic both have a tendency to start with the most thematic element" (p. 119). Example (1) is given by Dickens et. al (2002, p.119) to illustrate this fact:

$$
\text { و بنى هذا الجسر مهندسون مصريون. (1) }
$$

This bridge was built by Egyptian engineers.

Although the syntactic structure of the two sentences is different, they both put the bridge/ الجسرin the thematic position with the difference that Arabic places the verb بنى before the subject, while in English the verb 
'was built' followed it, which is attributed to the syntactic nature of the two languages, as already noted. Thus, because this study focuses on news reports whose basic syntax in Arabic is VSO, the verb in Arabic texts will be considered part of the theme, so that in example (8), the theme is بنى الجسر. Additionally, Al-Jayrudy (2011) justifies the consideration of the subject as part of the theme in Arabic verbal sentences through Halliday's (2004) analysis of theme in interrogative clauses in which he includes the implicit subject in close the window, or the explicit subject in let us go to the zoo in the theme position.

In English, a marked theme is "something other than the Subject, in a declarative clause" (Halliday, 2004, p. 73). Similarly, for Arabic, "anything which comes before the verb in a sentence which contains a verb may be a preposed emphatic theme" (Dickens, et. al, 2002, 118). Thus, thematic markedness occurs with any word order other than the basic VSO one. However, SVO is the conventional word order for headlines in Arabic news discourse, since it has been observed to have an "overwhelming presence in newspaper headlines" (Mellor, 2005, p. 120) and thus it is considered unmarked. A marked theme, according to Halliday (2004, p. 73), can be an adverbial group, e.g. today, consequently; a prepositional phrase, e.g. at noon, in the corner, or it can be a preposed complement which does not frequently occur as a subject as in you I blame, that they didn't tell us.

\section{Data Analysis}

The data for this study consists of 40 news reports, 20 English and 20 Arabic from four online news websites; the American liberal The New York Times, the British conservative the Telegraph, the Egyptian stateowned Al-Ahram, and the Qatar-based Al-Jazeera. The 40 news reports cover 10 major incidents in the period between February 2012 and July 2015. Each newspaper holds a different ideological as well as linguistic background, hence, enriching the study.

The 10 major incidents are:

1. Soccer riot in Port Said Stadium (1/2/2012)

2. Protests in Egypt following Anti-Islam Movie (11/11/2012)

3. Ahmadinejad of Iran's visit to Egypt (5/2/2013) 
4. Luxor balloon crash (26/2/2013)

5. Isis Declaration of Caliphate (29/6/2014)

6. 2014 Israel's ground invasion of Gaza (17/7/2014)

7. Ebola virus outbreak in West Africa (31/7/2014)

8. Shooting of Michael Brown in Ferguson, Missouri, USA $(10 / 8 / 2014)$

9. Charlie Hebdo Attack (7/1/2015)

10. Greece votes 'No' to EU austerity measures (5/7/2015)

\subsection{Thematization in the English news reports}

Representing two different ideologies, TG is a British conservative newspaper and NYT is an American Liberal one, both newspapers display variation in the information they choose to put in the most prominent position; the headline. Table 1 below shows the newspapers' macropropositions. The headlines of the two newspapers vary in terms of schematic structure, i.e., the schematic categories they choose to bring to the fore in the headlines, owing to the ideological differences between the two newspapers.

Table 1: Schematic structure of the English report headlines

\begin{tabular}{|c|c|c|}
\hline \multirow[t]{2}{*}{ Main Event } & \multicolumn{2}{|c|}{ Headlines } \\
\hline & TG & NYT \\
\hline $\begin{array}{l}\text { (1) Soccer riot } \\
\text { at Port Said } \\
\text { Stadium, } \\
\text { Egypt } \\
(1 / 2 / 2012)\end{array}$ & $\begin{array}{l}\text { Egyptian football violence: at } \\
\text { least } 70 \text { people dead after fire } \\
\text { and riot at Egyptian football } \\
\text { match } \\
\text { (Main Event + } \\
\text { Consequences) }\end{array}$ & $\begin{array}{l}\text { Egyptian Soccer Riot Kills More } \\
\text { Than } 70\end{array}$ \\
\hline $\begin{array}{l}\text { (2) Protests } \\
\text { against anti- } \\
\text { Islam movie } \\
(11 / 9 / 2012)\end{array}$ & $\begin{array}{l}\text { Egyptian protesters tear down } \\
\text { US embassy flag } \\
\text { (Consequences) }\end{array}$ & $\begin{array}{l}\text { Mysterious Anti-Muslim Movie } \\
\text { Prompts Protest in Egypt } \\
\text { (Comment + Main Event) }\end{array}$ \\
\hline $\begin{array}{l}\text { (3) } \\
\text { Ahmadinejad's } \\
\text { visit to Egypt } \\
(5 / 2 / 2013)\end{array}$ & $\begin{array}{l}\text { Iran's Ahmadinejad makes } \\
\text { historic visit to Cairo } \\
\text { (Main Event) }\end{array}$ & $\begin{array}{l}\text { Ahmadinejad Visits Egypt, } \\
\text { Signaling Realignment } \\
\text { (Main Event + } \\
\text { Comment/Evaluation) }\end{array}$ \\
\hline $\begin{array}{l}\text { (4) Luxor } \\
\text { Balloon crash } \\
(26 / 2 / 2013)\end{array}$ & $\begin{array}{l}\text { Egypt hot air balloon crash: } \\
\text { ' } 18 \text { tourists, including } \\
\text { Britons, killed' } \\
\text { (Main Event }+ \\
\text { Consequences) }\end{array}$ & $\begin{array}{l}\text { Egyptian Balloon Explosion } \\
\text { Kills at Least } 19 \text { Tourists at } \\
\text { Luxor } \\
\text { (Main Event + Consequences) }\end{array}$ \\
\hline
\end{tabular}




\begin{tabular}{|c|c|c|}
\hline $\begin{array}{l}\text { (5) ISIS } \\
\text { declares } \\
\text { caliphate in } \\
\text { Iraq and Syria } \\
(29 / 6 / 2014) \\
\end{array}$ & $\begin{array}{l}\text { Isis declares its captive } \\
\text { territories an 'Islamic } \\
\text { Caliphate' } \\
\text { (Main Event) }\end{array}$ & $\begin{array}{l}\text { Al-Qaida Splinter Declares New } \\
\text { Islamic Caliphate } \\
\text { (Comment + Main Event) }\end{array}$ \\
\hline $\begin{array}{l}\text { (6) } 2014 \\
\text { Israel-Gaza } \\
\text { conflict } \\
(17 / 7 / 2014)\end{array}$ & $\begin{array}{l}\text { Israel launches ground } \\
\text { offensive in Gaza } \\
\text { (Main Event) }\end{array}$ & $\begin{array}{l}\text { Israeli Military Invades Gaza, } \\
\text { With Sights Set on Hamas } \\
\text { Operations } \\
\text { (Main Event) }\end{array}$ \\
\hline $\begin{array}{l}\text { (7) Ebola Virus } \\
\text { Outbreak } \\
(31 / 7 / 2014)\end{array}$ & $\begin{array}{l}\text { Ebola Outbreak: We're } \\
\text { heading towards a } \\
\text { catastrophe, warns top medic } \\
\text { (Main Event + Verbal } \\
\text { Reaction) }\end{array}$ & $\begin{array}{l}\text { Emergency Efforts in Africa to } \\
\text { Contain Ebola as Toll Rises } \\
\text { (Main Event) }\end{array}$ \\
\hline $\begin{array}{l}\text { (8) Shooting of } \\
\text { Michael } \\
\text { Brown in } \\
\text { Ferguson, } \\
\text { Missouri } \\
(10 / 8 / 2014)\end{array}$ & $\begin{array}{l}\text { Protests after St. Louis police } \\
\text { shoot dead black teenager } \\
\text { (Consequences + Main } \\
\text { Event) }\end{array}$ & $\begin{array}{l}\text { Grief and Protests Follow } \\
\text { Shooting of a Teenager } \\
\text { (Consequences + Main Event) }\end{array}$ \\
\hline $\begin{array}{l}\text { (9) Charlie } \\
\text { Hebdo Attack } \\
\text { in Paris, } \\
\text { France } \\
(7 / 1 / 2015)\end{array}$ & $\begin{array}{l}\text { Charlie Hebdo attack: } \\
\text { France's worst terrorist attack } \\
\text { in a generation leaves } 12 \text { dead } \\
\text { (Main Event + Comment + } \\
\text { Consequences) }\end{array}$ & $\begin{array}{l}\text { Terrorists Strike Charlie Hebdo } \\
\text { Newspaper in Paris, Leaving } 12 \\
\text { Dead } \\
\text { (Main Event + Consequences) }\end{array}$ \\
\hline $\begin{array}{l}\text { (10) Greece } \\
\text { Votes 'NO' to } \\
\text { Austerity } \\
\text { Measures by } \\
\text { EU } \\
(5 / 7 / 2015)\end{array}$ & $\begin{array}{l}\text { Europe thrown into crisis as } \\
\text { Greece nears euro exit after } \\
\text { shock referendum result } \\
\text { (Comment/Evaluation + } \\
\text { Main Event) }\end{array}$ & $\begin{array}{l}\text { Greeks Reject Bailout Terms in } \\
\text { Rebuff to European Leaders } \\
\text { (Main Event + Comment) }\end{array}$ \\
\hline
\end{tabular}

Viewing the table above, it is easy to recognize how the schematic categories of headlines vary according to the involvement of each newspaper. On the whole, headlines of NYT, as a liberal newspaper, use the comment category in its reports more than TG, regardless of the degree of its involvement in the incident. This can be explained in the light of the US viewing itself as a great power, protecting the rest of the world. Interesting is the absence of the comment category in headline (8), about the shooting of the black teenager, Michael Brown. Since this is a local affair, the newspaper is cautious not to infuriate the public by adding a comment and be considered biased in any way. 
On the other hand, and in line with its conservative ideology, TG's headlines are more conventional in the sense that they comprise the normal categories expected to appear in headlines (e.g.

Consequences/Main Events). However, the Comment category makes it to the headline in two incidents that are considered local affairs to the UK. In headline (9) about the Charlie Hebdo attacks, TG inserts a comment (France's worst terrorist attack) because a terrorist attack in a neighboring country in Europe is threatening to the UK. Headline (10) about the Greek referendum displays a comment in the form of evaluation. Such incident is particularly important to the UK because it has effects on its economy.

An interesting difference between the two newspapers that further highlights the impact of their ideologies in determining the structure of the headlines is in headlines (2) and (3). These headlines report two incidents that are particularly important to the newspapers as Western. Headline (2) reports protests against an anti-Islam movie that originated in the US. While NYT manages to insert an implied comment (Mysterious Movie) that undermines the movie in the headline, TG reports the consequence of the protests and foregrounds it, threatening the face of the US. Headline (3) reports Ahmadinejad's (Iran's president then) visit to Egypt. TG reports the incident quite neutrally, mentioning only the Main Event. NYT, on the other hand, includes the Comment category (Signaling Realignment) in the headline which is probably a result of the long-time tensions between the US and Iran. It seems that the realignment of Iran and any other country, especially Egypt (because of its strategic importance), is of interest to the US.

Second, as shown in Table 2 below, the percentage of marked themes in NYT is higher than that of TG's. Marked themes are associated with persuasive argumentation and signal degrees of the intervention of the writer (Francis, 1990, p 60; Francis \& Kramer-Dahl, 1991, p. 354). Thematized elements "provide not only a starting point around which what follows in the discourse is structured but also a starting point which constrains our interpretation of what follows" (Brown \& Yule, 1983, p. 139). Therefore, NYT's style is more persuasive than TG's, imposing the 
newspaper's point of view on the readers and paving the way for bias to take place.

Table 2: Number and percentage of marked and unmarked themes in the English reports

\begin{tabular}{lllll}
\hline Theme Type & TG & \multicolumn{3}{l}{ NYT } \\
\hline & No. & $\%$ & No. & $\%$ \\
\hline Marked Themes & 60 & 10.69 & 123 & 14.28 \\
\hline Unmarked Themes & 501 & 89.30 & 738 & 85.71 \\
\hline Total & 561 & 100 & 861 & 100 \\
\hline
\end{tabular}

Marked themes contribute to the enabling of bias because they are a clue that reporters arrange pieces of discourse in a way that affects the readers' perception of the information, rather than merely reporting an incident. Imposing certain pieces of information or comments on the readers makes them understand the incident within a mental framework that serves the newspaper's ideology.

In many incidents, the two newspapers inserted comments in a thematized position, bringing such comments to the fore and forcing readers to perceive what follows in their light. For example, when reporting the soccer riots, NYT makes use of marked themes as a discourse strategy to focus attention on certain information.

(2) a) The deadliest soccer riot anywhere in more than 15 years, [theme] it also illuminated the potential for savagery among the organized groups of die-hard fans known here as ultras.

b) In a rare impromptu statement, [theme] Egypt's top military officer, Field Marshal Mohamed Hussein Tantawi, vowed in a phone call to Al Ahly's satellite channel that the military would apprehend those responsible

(NYT\#1)

In (2-a), the thematization of the superlative deadliest, the adverb anywhere, and the rhetorical effect of the number 15 years highlights the horridness of the riots and draws attention to its multifaceted ramifications expressed in the rheme. Additionally, in (2-b), the reporter is drawing attention to the rarity of the top military officer's improvised statements. While this points out the disciplined nature of the military, it also refers to previous cautiously-written statements released by them and thus highlighting the grossness of the situation that drove the top military officer to improvise a statement. 
In the reports about the Charlie Hebdo attacks, both newspapers use marked themes to insert their comments, though in different directions.

(3) a) With ruthless precision, [theme] two masked al-Qaeda gunmen calmly fire eight shots at an unarmed policeman as a terrorist attack of "indescribable barbarity" nears its end.

b) Armed with Kalashnikov assault rifles, ammunition jackets and, according to one report, a grenade launcher, [theme] the killers were triumphant as they left the office, shouting: "We have killed Charlie Hebdo! We have avenged the Prophet Mohammed!"

(TG\#9)

c) Treasured by many, hated by some and indiscriminate in its offensiveness, [theme] Charlie Hebdo has long reveled in provoking.

(NYT\#9)

In the examples above, TG uses the marked theme to bring to the fore its comment on the way the terrorists implemented their attack as well as the weaponry they used ( $3 a-b)$. On the other hand, NYT, showing a more balanced tone, devotes its marked theme to comment on the Charlie Hebdo magazine, indirectly rationalizing such attack on the paper.

Another incident where the marked themes are utilized ideologically is the report about the Greek referendum.

(4) a) While the Greek finance minister, Yanis Varoufakis, said that a deal could be hammered out within 24 hours, [theme] EU officials said that prospects of a new deal were far from clear.

b) While there had been speculation about Mr. Tsipras stepping down in the event of a yes vote, [theme] the man he succeeded as prime minister, Antonis Samaras, the leader of the New Democracy Party, announced his resignation, saying, "I understand that our great party needs a new start."

c) After five years in which unemployment soared beyond 20 percent and the country's economy contracted by 25 percent, [theme] many said that a no vote was at least a vote for hope, the possibility of a new deal, rather than following the mandates of creditors who had failed to set Greece on a course to recovery.

(NYT\#9)

In (4-a), TG uses the marked theme to threaten the face of the Greek finance minister. The contrast between the marked theme (what the finance minister says) and the rheme (what the EU officials say) proves that the minister's words are valueless. On the other hand, in (4-b), NYT 
thematizes a positive trait of Tsipras, the Greek prime minister, portraying him as a bold leader who, unlike his counterparts, chose to face the situation bravely. In (4-c), the report accentuates the audacity of the Greek people, stating that, in spite of the dire economic status, they are willing to take risks to save their country.

Marked themes in the report about the Ebola outbreak have been used by the newspapers to highlight the incompetence of the African leaders and marked themes are the perfect tool to further that argument.

a) In a further sign of disagreement over how to respond to the outbreak, [theme] the leader of the Ebola task force in Guinea said moves by neighbouring Liberia to shut all schools to contain the disease could prove counter productive..

(TG\#7)

b) As the death toll mounted from the worst outbreak of the Ebola virus, [theme] West African leaders quickened the pace of emergency efforts on Thursday.

(NYT\#7)

As can be seen, both newspapers place a comment in the thematized position to embarrass the African leaders and emphasize their ineptitude. In (5-a), TG thematizes the disagreement surrounding the response to the outbreak which is a clue to the random and haphazard manner with which the African leaders are handling the situation. On the other hand, NYT (5-b) stresses the worsening state of the outbreak, hence, hinting at the insufficient efforts by the African leaders.

When reporting the Gaza-Israel 2014 conflict, marked themes are utilized to exonerate Israel from any accusations.

(6) a) After the deaths of 236 Palestinians and one Israeli, (theme) Operation Protective Edge escalated into a ground campaign on its tenth day.

(TG\#6)

b) As rockets continued to rain down on Israeli cities, (theme) a military spokesman said the mission's expansion was "not time bound"

(NYT\#6)

In both examples, the Israeli attack is rationalized as an act of selfdefense through placing Hamas' rockets raining on Israeli cities in the theme position (6-b). As a matter of fact, the marked theme in (6-a) is 
somehow ironic because first, it equates between the number of deaths of the Palestinian and the Israeli side and second, because it forces upon the readers that such a reason is valid for Israel to launch its ground offensive.

Spatial and temporal marked themes abound in both reports. They are considered story-telling devices that help advance the narrative and suit the nature of the text as a report. However, their thematization might also have an ideological effect.

(7) a) In Cairo, [theme] the die-hard fans of the capital's Zamalek club, usually archrivals of Al Ahly, abandoned a match in midgame in solidarity with the team, burning their signs as they usually do at the end

b) And by the end of the night, [theme] the league had suspended its schedule.

c) By 2 a.m. Thursday, [theme] a new wave of protests had begun, blaming the military-led government for allowing the deaths of the fans.

d) In Cairo, [theme] demonstrators against military rule who had been camped out by the state television building moved their vigil to the Ahly headquarters.

(NYT\#1)

In (7 a-d) above, the thematization of the spatial marked themes when reporting the soccer riots in Port Said, is done to indicate the effect of such riots on the rest of the country; that protests broke out in the rest of Egypt against such violence. A temporal theme of ideological importance is also present in TG's report about Charlie Hebdo Attacks.

(8) For several years, [theme] Europe's intelligence services have feared that Muslim extremists who have travelled to Syria, Iraq and elsewhere to fight would return home to plot carnage.

(TG\#9)

TG chooses to thematize the temporal adverb for several years to show the extent of Muslim extremists' threat and that it has been a major concern for a long time.

\subsection{Thematization in the Arabic news reports}

Coming from two different ideological backgrounds, $\mathrm{AH}$ and $\mathrm{AJ}$ display variation in the information they choose to put in the most prominent position; the headline. Table 3 below shows the newspapers' macropropositions. The headlines of the two newspapers vary in terms 
of the schematic categories they choose to bring to the fore in the headlines.

Table 3: Schematic structure of the Arabic report headlines

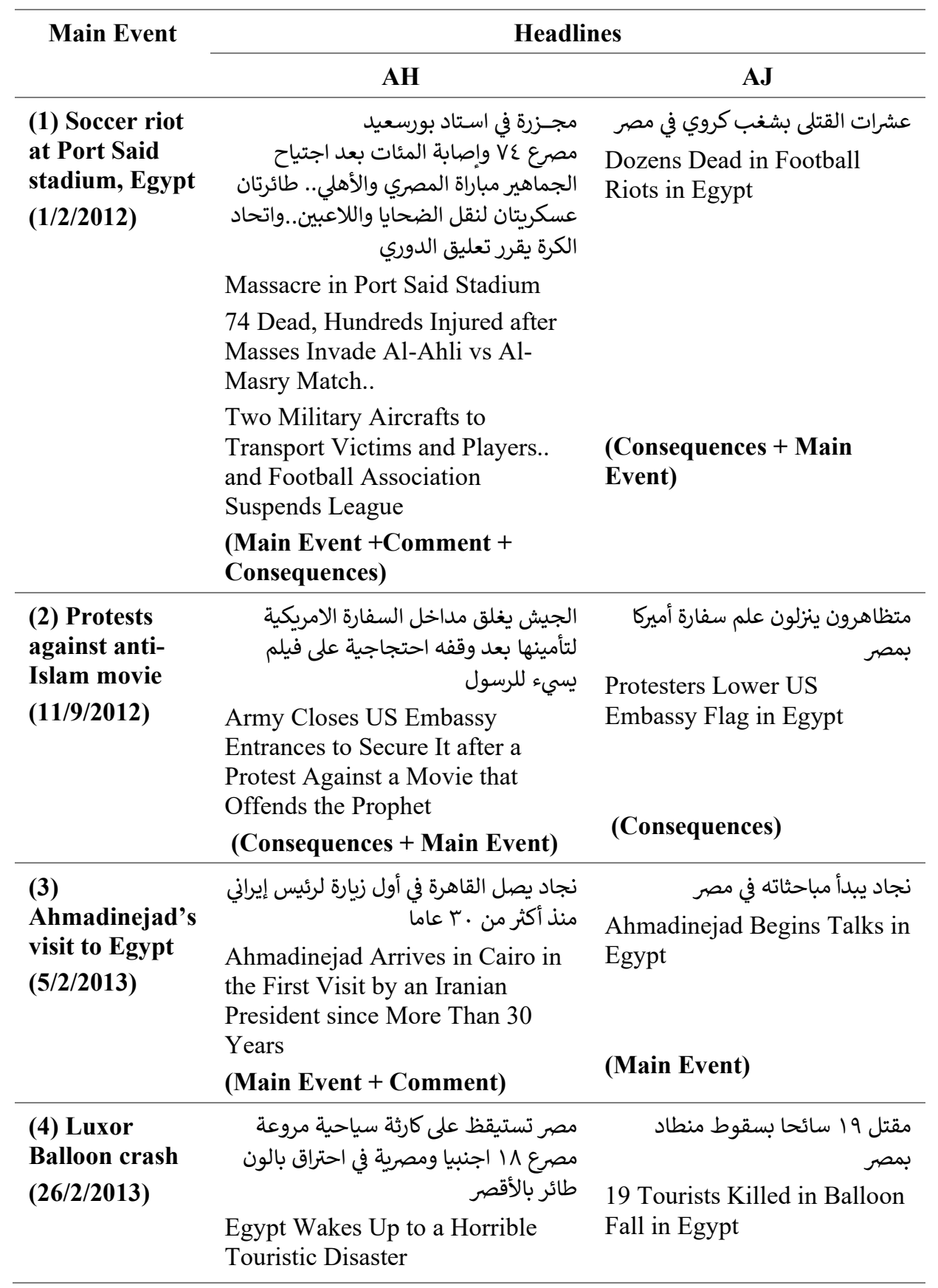


18 Foreigners and 1 Egyptian

Dead in a Balloon Explosion in

Luxor

(Comment + Consequences + Main Event)

\begin{tabular}{|c|c|}
\hline $\begin{array}{l}(5) \text { ISIS } \\
\text { declares } \\
\text { caliphate in } \\
\text { Iraq and Syria } \\
(29 / 6 / 2014)\end{array}$ & $\begin{array}{l}\text { خلافة 》داعشه "وهم سيتبدد بسرعة " } \\
\text { ISIS” Caliphate is an Illusion “ } \\
\text { that Will Quickly Wear } \\
\text { (Main Event + } \\
\text { Comment/Evaluation) }\end{array}$ \\
\hline $\begin{array}{l}\text { (6) } 2014 \\
\text { Israel-Gaza } \\
\text { conflict } \\
(17 / 7 / 2014)\end{array}$ & 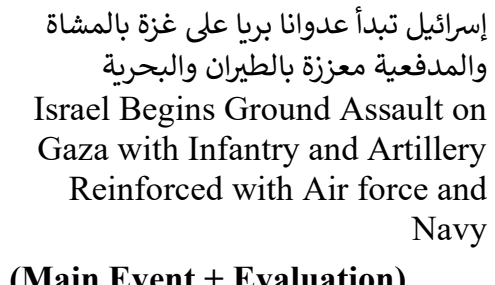 \\
\hline $\begin{array}{l}\text { (7) Ebola Virus } \\
\text { Outbreak } \\
(31 / 7 / 2014)\end{array}$ & 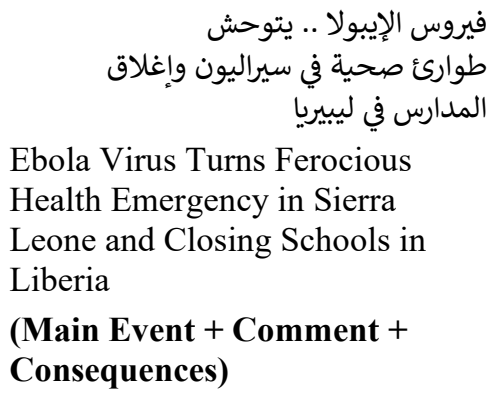 \\
\hline
\end{tabular}

(Consequences + Main

Event)

$$
\text { ““تنظيم الدولة”” يعلن الخلافة ويبايع }
$$

البغدادي

"Islamic State" Declares

Caliphate and Pledges

Allegiance to Al-Boghdadi

(Main Event)

$$
\text { إسرائيل تبدأ هجوما بريا على غزة }
$$

Israel Begins Ground Attack

on Gaza

(Main Event)

$$
\text { سيراليون تعلن حالة الطوارئ }
$$

Sierra Leone Declares State of Emergency to Face Ebola

\section{(Consequences + Main Event)}

(8) Shooting of اشتباكات بين السود والشرطة في ميزورى إثر Michael

Brown in

Ferguson,

Missouri

(10/8/2014)
مقتل شاب

Clashes between Blacks and the

Police in Missouri Following the Killing of a Young Man

(Consequences + Main Event)
احتجاجات على مقتل شاب برصاص شرطي بميسوري

Protests Over the Killing of a Young Man Shot Dead by a Policeman in Missouri

(Consequences + Main Event)

(9) Charlie Hebdo Attack in Paris, France (7/1/2015)

$$
\text { شتلى بهجوم مسلح على صحيفة }
$$

Deaths in an armed attack on the French newspaper Charlie Hebdo

$$
\text { الإرهاب يضرب فرنسا في قلبها }
$$

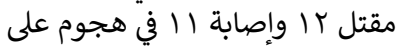
صحيفة 》شارلى إبدو "الساخرة

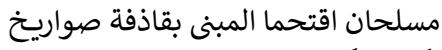
وكلاشينكوف.. وهتفا "انتقمنا للرسولين صواريخ

Terrorism Strikes France at Its Heart 
12 killed, 11 injured in an Attack

on the Satirical Newspaper

«Charlie Hebdo»

Two Gunmen Broke into the Building with a Rocket Launcher and Kalashnikov.. and Shouted

(Consequences + Main Event)

«We Have Avenged the Prophet»

(Comment + Consequences + Main Event)

(10) Greece Votes 'NO' to Austerity Measures by EU $(5 / 7 / 2015)$
اليونانيون يرفضون خطة أورويا للإصلاح..

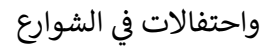
تراجع اليورو أمام الدولار... وبرلين:

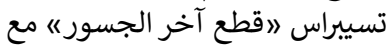
الأوروبيين

Greeks Reject Europe's Reform Plan.. Celebrations in the Streets Euro falls Against US Dollar .. and Berlin: Tsipras «Tore Down the Last Bridges» with the Europeans

(Main Event + Consequences + Verbal Reaction)
“لا” يونانية لخطة الإنقاذ الأوروبية

A Greek "No" to the

European Rescue Plan

(Main Event)

Viewing the table above, it is clear that, on the whole, AH's headlines are more informative than AJ's as various news categories make it to its headlines other than the Main Event. Thus, AH's headlines are characterized by being multipartite where the reporters choose to put the information they view as most important and most valuable for their readers. Additionally, the Comment category is visible in almost all of AH's headlines, regardless of the incidents' proximity to Egypt, while it is totally absent from AJ's.

As a matter of fact, in AH's headline \#5 about the ISIS declaration of their caliphate, the Main Event is backgrounded by means of existential presupposition, and the comment is brought to the fore, signaling a severe bias by the report. Interestingly, however, the Comment category is absent from AH's headline about the protests against the anti-Islam movie, and the Consequences precede the Main Event. This can be explained through the fact that the incident is a local affair that threatens the Egypt-US relations and hence it is important for the newspaper to 
assure that Egypt is concerned with the safety and security of American entities in the country.

Moreover, the multipartite nature of AH's headlines allows for bias to take place where certain pieces of information are foregrounded. In headline \#1 about the soccer riots in Port Said, AH makes sure to include the fact that Two Military Aircrafts were sent to transport the players and the injured, which only serves to undermine the role of the police who are described as helpless by the report.

In reporting the Charlie Hebdo attacks, headline \#9, the report exploits its multiple nature and includes information that would otherwise be reserved to the body of the report. The detailed description of the Main Event is foregrounded in the headline to guarantee that the reader does not miss such information, hence increasing the impact of the terrorist attack.

Reporting the Greek 'No' to EU austerity measures, headline \#10, also displays the same pattern. AH includes and foregrounds a negative consequence of the 'No' vote; Euro falls against US Dollar, which counts as an implied comment on the Greeks' decision.

As for AJ, it can be concluded that it tries to stick to the tenets of objective journalism more than AH. However, this can also result in bias. In reporting the shooting of Michael Brown in Missouri, USA, headline \#8, AJ is actually less informative than it should be, since it disregards the racial nature of the clashes and omits the fact that the boy who is shot dead is a black person. This is done by the report to background the racial undertones and foreground police brutality.

Also, in reporting the protests against the anti-Islam movie, AJ in fact does not include the Main Event in the headline and chooses to foreground the consequences of the protest; that the protesters lowered the US flag. Including such information in the most prominent position in a news report counts as bias by AJ, which tries to evoke an anti-US sentiment, because no specific reason is given in the headline for the protesters to lower the US flag. This works in AJ's favor and antagonizes the US. 
Second, as for marked themes and as shown in table 4 below, the percentage of marked themes is higher in AH than in AJ, hence, AH's style adopts a more persuasive pattern of reporting than AJ, imposing its point of view on the readers and paving the way for bias to take place.

Table 4. Number and percentage of marked and unmarked themes in the Arabic reports

\begin{tabular}{lllll}
\hline Themes & AH & & AJ & \\
& No. & $\%$ & No. & $\%$ \\
\hline Marked Themes & 52 & $23.42 \%$ & 32 & $16.75 \%$ \\
\hline Unmarked Themes & 170 & 76.57 & 159 & 83.24 \\
\hline Total & 222 & 100 & 191 & 100 \\
\hline
\end{tabular}

Marked themes in the Arabic reports are expressed in two ways. Because the nature of Arabic news reports syntax follows a VS word order, any clause that has SV syntax is viewed as having a marked theme. Second, marked themes are also realized when certain blocks of the sentence are fronted to create an ideological effect. Below are some examples from the corpus.

$$
\text { a وهذه هي المرة الأولي التي يتمكن فيها محتجون من صعود سور السفارة الأمريكية. }
$$

This [theme] is [rheme] the first time that protesters are able to climb the wall of the US Embassy.

$$
\text { لإيذاء مشاعر المسلمين الدينية. }
$$

The US Embassy in Cairo [theme] has condemned [rheme] the continued attempts by some misguided individuals to hurt the feelings of Muslims.

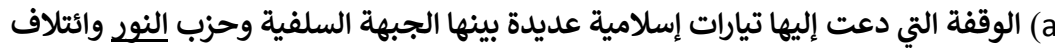

$$
\begin{aligned}
& \text { المسلمين الجدد، بدأت بالمئات وسرعان ما تزايد العدد ليصل إلى الآلاف. }
\end{aligned}
$$

The protest organized by many Islamic movements, including the Salafi front, Nour Party, and a coalition of neo-Muslims, [theme] began [rheme] in the hundreds and quickly grew to thousands.

$$
\text { b وكانت الجماعة الإسلامية قد استبقت الوقفة بإصدار بيان ينتقد منتجي الفيلم المسيء. }
$$

The Islamic group [theme] has pre-empted [rheme] the protest by issuing a statement criticizing the producers of the offensive film.

$$
\text { إلى محاولات لاقتحامها. }
$$


After these developments [theme], police and army forces flocked to the embassy [rheme] in case the anger development turns into attempts to storm it.

In the above examples, both reports make use of nominal sentences to focus on a certain piece of information. In (9-a), the nominal sentence is used as a strategy to save the face of the US, where the information that what the protesters are doing, climbing the embassy walls, is unprecedented is brought to the fore via diverting from the original word order. On the other hand, AJ uses its nominal sentence to bring to the fore the protest and the parties who called for its organization (10-a). This markedness serves AJ's goals and goes in line with its Islamic orientation.

In (9-b) and (10-b), the verb kaanat, signals a marked theme since it is an empty verb that only occurs in nominal clauses. While AH chooses to foreground the US Embassy statement (9-b), AJ foregrounds the statement issued by the Islamic group (10-b). In (10-c), AJ fronts the adverbial adjunct بعد هذه التطورات/after these developments (referring to the escalations of the protest) to frame the presence of the police forces in the light of these developments and assure that the protests are safe and legitimate.

Another instance of a marked theme is used by AJ when reporting Ahmadinejad's visit to Egypt:

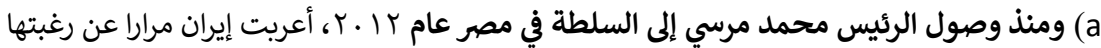

$$
\begin{aligned}
& \text { في تطبيع علاقاتها مع القاهرة. } \\
& \text { لكن السلطة المصرية الجديدة أعريت حتى الآن عن تحفظ بشأن هذا الموضوع. b }
\end{aligned}
$$

but Egypt's new authority [theme] has expressed a reservation [rheme] on this issue until now.

In the above examples, $\mathrm{AJ}$ makes sure to foreground the authority of the (nowousted) MB president through thematizing the information (11-a), which also frames Iran as weak and persistent, giving a time frame for its expression of 
willingness to restore relations with Egypt. In (11-b), the nominal sentence foregrounds Egypt's new authority and gives it textual prominence.

Other examples by AH include the following:

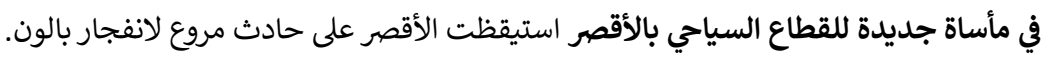

In a new tragedy for the Luxor tourism sector [theme], Luxor woke up to a horrible accident of a balloon explosion. [rheme]

(AH\#4)

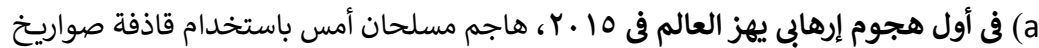

$$
\begin{aligned}
& \text { وكلاشينكوف مقر صحيفة "شارلى إبدو " الساخرة في قلب أبم باريس. }
\end{aligned}
$$

In the first terrorist attack that shakes the world in 2015 [theme], two gunmen attacked the satirical newspaper Charlie Hebdo headquarters [rheme] with a rocket launcher and a Kalashnikov

$$
\text { وفور الإعلان عن الهجوم، هرع الرئيس الفرنسي فرانسوا أولاند إلى موقع الحادث. b }
$$

As soon as the attack was announced, [theme] the French president Francois Hollande rushed to the sight of the accident

$$
\text { وعدم التمكن من التوصل الى اتفاق مع الدائنين قد يدفع باليونان الى الخروج من منطقة اليورو. }
$$

The inability to reach an agreement with creditors [theme] could push Greece out of the euro zone [rheme].

In (12) and (13 a-b), AJ thematizes adjuncts that frame the following information in an ideological way. Readers are compelled to comprehend the tragedy of the Luxor balloon crash in the light of previous tragedies, activating previous models in the minds of the readers, hence magnifying the impact of such a crash (12). The same is done in (13-a), where AH thematizes its comment and imposes it upon the reader. The reader has no way but to interpret the attack as an attack that shook the world. The marked theme in (13-b), coupled with the hyperbolic verb rushed in the rheme, puts Hollande's action in a time frame that matches the horridness of the incident.

In (14), AH resorts to the nominal sentence to thematize the possibility of Greece's inability to reach an agreement with the European creditors to bring it to the fore and frame the No vote in the reader's mind as having bad consequences. 


\section{Conclusion}

This paper has attempted to investigate how ideological bias is linguistically expressed and manifested in Arabic and English news reports through thematization analysis and how this is used to frame news events in a favorable ideological direction. On the whole, the four newspapers remained true to their respective ideologies. The analysis has revealed that each newspaper fluctuated on the neutrality-bias scale according to the incident reported.

There are also some interesting differences between Arabic and English newspapers. First, with regard to headlines and their schematic categories, it has been found that each newspaper adjusts its schematic categories in the way that best serves its ideological goals. The Comment Category is the vehicle for bias in headlines and its detection coincides with the newspaper's ideological involvement. NYT's headlines signal its brazen engagement in any incident that includes the Unites States, either by being biased or by being less informative than required to save US face, in spite of its liberal inclinations (e.g. the Shooting of the black teen incident). TG, on the other hand, ostensibly stays true to its conservative ideology, which is, betrayed whenever Europe is the main news event (e.g. Grexit and the Charlie Hebdo attack). An exception in the Arabic newspapers to this is AJ which sticks to the objective schematic categories predicted to be present in headlines. In spite of its Qatari affiliations, AJ always claims to be an international media institution that gives space to opposing opinions equally. However, less informative headlines triggers bias as well. Finally, AH's headlines have the characteristic feature of being multi-partite. This feature allows bias to take place through including various types of categories and gives the chance to reporters to include whatever information they ideologically view as relevant.

Second, marked themes analysis reveals the Arabic news reports' dependence on thematic markedness more than the English ones. It is important to note that, because Arabic, unlike English, has the options of nominal and verbal sentences and because the nature of Arabic news reports syntax follows a VS word order, any clause that has SV syntax is 
viewed as having a marked theme. Hence, Arabic marked themes are more subtle and less obvious to the readers to comprehend. Additionally, the English marked themes include comments inserted and fronted by the reporter in order to frame the subsequent information in the light of the thematized chunk of the sentence. On the other hand, Arabic, by means of the nominal sentence, mainly displays bias through fronting the news actors of the processes and giving them prominence, though some examples of fronted chunks of discourse are also detected.

The paper has thus attempted to provide a view as comprehensive as possible of the linguistic manifestations of ideological bias through thematization. While most of CDA studies are only limited to one topic or deal with one problem and investigate its linguistic realization, this study has adopted a panoramic view through analyzing diverse topics from different fields, including economic, medical, political, and sports news events. This diversity coupled with the diverse ideological and linguistic backgrounds has made the results as all-inclusive as possible. Additionally, the aim is to illustrate that ideology is pervasive and ubiquitous in news texts whatever news event is reported, and through clarifying the vehicles of bias in the news, it is hoped that readers become more critical and able to assess the information presented to them rather than passively perceiving reality and allowing news producers to shape their perception of events.

\section{References}

Al-Jayrudy, L. (2011). Ideological representations in English and Arabic news reports: A thematic structure analysis. (Unpublished $\mathrm{PhD}$ thesis). School of Management and Languages, Heriot-Watt University, Edinburgh. Retrieved March 22, 2020 from https://cutt.ly/8hPohBX

Althusser, L. (1969). For Marx. (B. Brewster, Trans.) London: Verso.

Althusser, L. (1971). Lenin and philosophy, and other essays. (B. Brewster, Trans.) New York: Monthly Review Press.

Barker, C. \& Galasiński, D. (2001). Cultural studies and discourse analysis: A dialogue on language and identity. London: Sage Publications.

Bazzi, S. (2009). Arab news and conflict: A multidisciplinary discourse study (discourse approaches to politics, society and culture). Amsterdam: John Benjamins.

Bell, A. (1991). The language of news media. Oxford: Blackwell.

Brown, G. \& Yule, G. (1983). Discourse analysis. Cambridge: Cambridge University Press.

Dickins, J., Hervey, S., \& Higgins, I. (2002). Thinking Arabic translation: A course in translation method: Arabic to English. London: Routledge. 
Fairclough, N. (1989). Language and power. London: Longman.

Fairclough, N. (1992). Discourse and social change. Cambridge: Polity Press.

Fairclough, N. (1994). Conversationalization of public discourse and the authority of the consumer. In R., Keat \& N., Whiteley \& N, Abercrombie (Eds.), The authority of the consumer (pp. 235-249). London: Routledge.

Fairclough, N. (1995a). Critical discourse analysis: The critical study of language. London: Longman.

Fairclough, N. (1995b). Media discourse. London: Hodder Arnold.

Fowler, R. (1991). Language in the news: Discourse and ideology in the press. London: Routledge.

Fowler, R. (1996). On critical linguistics. In C.R. Caldas-Coulthard and M. Coulthard (Eds.), Texts and practices: Readings in critical discourse analysis (pp.3-14). London: Routledge.

Fowler, R., Hodge, B., Kress, G., \& Trew, T. (1979). Language and control. London: Routledge.

Francis, G. (1990). Theme in the daily press. Occasional Papers in Systemic Linguistics, 4, $51-87$.

Francis, G. \& Kramer-Dahl, A. (1991). From clinical report to clinical story: Two ways of writing about a medical case. In E. Ventola (Ed.), Functional and systemic linguistics: Approaches and uses (pp. 339-368). Berlin: Mouton De Gruyter.

Gee, p. (1999). An introduction to discourse analysis: Theory and method. London: Routledge.

Hall, S. (2005). The problem of ideology: Marxism without guarantee. In D. Morley and K. H. Chen (Eds.), Stuart Hall: Critical dialogues in cultural studies (pp. 28-44). London: Routledge.

Halliday, M.A. K. (1976). Anti-Language. American Anthropological Association, 78(3), $570-584$.

Halliday, M. A. K. (2004). An introduction to functional grammar ( $3^{\text {rd }}$ edition). London: Arnold.

Herman, E. S., \& Chomsky, N. (1988). Manufacturing consent: The political economy of the mass media. New York: Pantheon.

McNair, B. (2003). News and journalism in the UK. London: Routledge.

Mellor, N. (2005). The making of Arab news. Oxford: Rowman and Littlefield.

Meyer, M. (2001). Between theory, method, and politics: Positioning of the approaches to CDA. In R., Wodak, \& M., Meyer (Eds.), Methods of critical discourse analysis (pp. 14-31). London: Sage Publications.

Payne, M., Barbera, J. R. (2010). A dictionary of cultural and critical theory. Chichester: Wiley-Blackwell.

Richardson, J. E. (2007) Analysing newspapers: An approach from critical discourse analysis. Houndmills: Palgrave Macmillan.

Van Dijk, T. A. (1985). Structures of news in the press. In T. A. van Dijk (Ed.), Discourse and communication. Berlin: De Gruyter, pp. 69-93.

Van Dijk, T.A. (1986). News schemata. In S. Greenbaum \& Cooper (Eds.), Studying writing: Linguistic approaches (pp. 155-186). Beverly Hills: Sag.

Van Dijk, T. A. (1988). News as discourse. Hillsdale, NJ: Erlbau.

Van Dijk, T.A. (1995a). Discourse analysis as ideology analysis. In C. Schäffner \& A. Wenden (Eds.), Language and peace (pp. 17-33). Aldershot: Dartmouth Publishig. 
Van Dijk, T. A. (1995b). Power and the news media. In D. Paletz (Ed.), Political communication and action (pp. 9-36). Cresskill, NJ: Hampton Pre.

Van Dijk, T. A. (1997). Cognitive context models and discourse. In M. Stamenow (Ed.), Language structure, discourse and the Access to consciousness (pp. 189226). Amsterdam: John Benjamins.

Van Dijk, T.A. (2001). Critical discourse analysis. In D. Schiffrin, D. Tannen, \& H. Hamilton (Eds.), The handbook of discourse analysis (pp. 352-371). Oxford: Blackwell.

Van Dijk, T. A. (2006). Ideology and discourse analysis. Journal of Political Ideologies, $11(2), 115-40$.

Van, Dijk T. A. (2008) Discourse and context: A socio-cognitive approach. Cambridge: Cambridge UP.

Wilcox, C. (2011). Bias: The unconscious deceiver. Bloomington, Indiana: Xlibris Corporati.

Wodak, R. (2001). What CDA is about - a summary of its history, important concepts and its development. In R., Wodak, \& M., Meyer. (Eds.) Methods of critical discourse analysis (pp. 1-13). London: Sage Publications. 